University of Nebraska - Lincoln

DigitalCommons@University of Nebraska - Lincoln

$1-2020$

\title{
The Increasing Opportunity Cost of Sequestering CO2 in the Brazilian Amazon Forest.
}

Felipe de Figueiredo Silva

Clemson University, fdsilva@clemson.edu

Lilyan E. Fulginiti

University of Nebraska, Ifulginiti@unl.edu

Richard Perrin

University of Nebraska-Lincoln, rperrin1@un.edu

Marcelo J. Braga

Universidad Federal de Viçosa, mjbraga.ruralprosper@gmail.com

Follow this and additional works at: https://digitalcommons.unl.edu/ageconfacpub

Part of the Agricultural and Resource Economics Commons

Silva, Felipe de Figueiredo; Fulginiti, Lilyan E.; Perrin, Richard; and Braga, Marcelo J., "The Increasing Opportunity Cost of Sequestering CO2 in the Brazilian Amazon Forest." (2020). Faculty Publications: Agricultural Economics. 215.

https://digitalcommons.unl.edu/ageconfacpub/215

This Article is brought to you for free and open access by the Agricultural Economics Department at DigitalCommons@University of Nebraska - Lincoln. It has been accepted for inclusion in Faculty Publications: Agricultural Economics by an authorized administrator of DigitalCommons@University of Nebraska - Lincoln. 


\title{
The increasing opportunity cost of sequestering $\mathrm{CO}_{2}$ in the Brazilian Amazon
}

\section{forest.}

\author{
Felipe de Figueiredo Silva, PhD (contact person) \\ Clemson University \\ fdsilva@clemson.edu \\ 235 McAdams Hall, \\ Clemson University \\ Clemson, SC 29632
}

\section{Lilyan E. Fulginiti, PhD}

University of Nebraska-Lincoln

307C Filley Hall

University of Nebraska-Lincoln

Lincoln, NE 68583-0922

\section{Richard K. Perrin, PhD}

University of Nebraska-Lincoln

208B Filley Hall

University of Nebraska-Lincoln

Lincoln, NE 68583-0922

\section{Marcelo Jose Braga, PhD}

Universidade Federal de Viçosa

Avenida P H Rolfs, Campus Universitário

Universidade Federal de Viçosa

Viçosa, MG-Brazil 36571-000

\section{Declarations}

This project is based on research that was partially supported by the Nebraska Agricultural

Experiment Station with funding from the Hatch Multistate Research capacity funding program (Accession Numbers NEB 1011054, NEB 227784) from the USDA National Institute of Food and Agriculture.

The authors declare no conflicts of interest or competing interests.

Data and software codes are available upon request from the corresponding author at fdsilva@clemson.edu

FFS, LEF, RKP and MJB conceived the research approach and wrote results, FFS coded data. 


\title{
The increasing opportunity cost of sequestering $\mathrm{CO}_{2}$ in the Brazilian Amazon forest.
}

\begin{abstract}
Bush fires raged across the Brazilian Amazon in 2019. The $\mathrm{CO}_{2}$ that was sequestered in those forests is now in the atmosphere, adding to the rate of global warming. The burned-over land will likely be converted to agriculture. Possible contributors to these events include climate change itself, creating hotter, drier conditions, and what is reportedly a reduction in the vigor of forest preservation efforts under a new government. But here we explore a third possible contributor: technical change may have been increasing the incentives to convert forests to agriculture. We examine the nature of technical change from 2003 to 2015, across 287 municipalities within Brazil's “arc of deforestation”. We consider grains, livestock and timber as agricultural outputs and $\mathrm{CO}_{2}$ emission from deforestation as an undesirable output. On average across the region, we estimate the annual rate of technical change in agriculture over this period to have been $4.9 \%$, with a significant bias toward agricultural outputs and away from $\mathrm{CO}_{2}$ emissions, meaning that it has been increasingly attractive to convert these forests to agriculture. This technological incentive for deforestation has thus been building up during the early part of this century, but actual deforestation was held in check somewhat by forest preservation policies until recently, when a more relaxed policy environment has allowed the increased technological incentive for deforestation to be more fully expressed. These changes have added to climate change as contributors to the recent burst in Amazon forest destruction.
\end{abstract}

Key words: $\mathrm{CO}_{2}$ sequestration, Amazon Forest, agricultural productivity, technical change biases. JEL: O44, Q55, Q15. 


\section{INTRODUCTION}

Brazil encompasses the largest tropical forest in the world, corresponding to more than $10 \%$ of the world's forest area and around 60\% of Brazil's surface (MacDicken et al., 2016). Strong agricultural expansion in the Amazon region, starting in the 1990s, has been closely related to deforestation and therefore to deforestation-related $\mathrm{CO}_{2}$ emissions. The increased agricultural output is a "good", but the related increase in $\mathrm{CO}_{2}$ emissions is a "bad", given its critical role in global warming. This paper addresses the changes in the technological tradeoff (marginal rate of transformation) between increased agricultural production (goods) and increased $\mathrm{CO}_{2}$ emissions (a bad).

In this article, we estimate the rate and biases of technical change for the "arc of deforestation" in the Brazilian Amazon during 2003-2015, including in the analysis deforestation as a proxy for $\mathrm{CO}_{2}$ emissions. Specifically, we measure both the rate of technical change and its effect on the opportunity cost of reducing $\mathrm{CO}_{2}$ emissions by forest preservation, i.e., whether technical change has been biased toward agricultural production or toward reductions of $\mathrm{CO}_{2}$ emissions from reductions in deforestation. To do this we estimate a municipality-level production possibility frontier (PPF) for agriculture for the period 2003 to 2015 . This permits us to identify whether technical change was progressive or regressive, and whether technical change was biased toward or against $\mathrm{CO}_{2}$ emissions from deforestation.

Even though our analysis does not include information after 2015, in particular that which is relevant to the recent fires and deforestation, it does help understand the increasing pressure to deforest given the increasing opportunity cost we estimate. 


\section{BACKGROUND}

In the literature, the "arc of deforestation" has been loosely defined as the set of municipalities in the agricultural frontier in the northern region of Brazil with high levels of deforestation. In this article, we investigate technical change in agriculture when deforestation as a proxy for $\mathrm{CO}_{2}$ emissions is also considered. We use information from 287 municipalities in nine states: Acre, Amazônia, Roraima, Rondônia, Amapá, Pará, Mato Grosso, Tocantins and Maranhão. Figure 1 illustrates total deforestation by municipality during the period 2001 to 2015 .

\section{[Figure 1]}

Rivero et al. (2009) assert that high rates of deforestation between 1995 and 2006 were caused partially by grain and livestock expansion in the North and Midwestern regions. In addition to these two activities, timber revenue has also been identified as a motivation for deforestation [Rivero et al. (2009); Margulis (2004); Cardille et al. (2003); Nepstad et al. (2001); Quintanilha and Lee Ho (2005)]. Other studies that also highlight the positive relationship between overall agriculture or a specific crop such as timber and deforestation in Brazil are Reis and Guzmán (1992), Andersen et al. (2002), Diaz and Schwartzman (2005), Nepstad et al. (2007), Araujo et al. (2009), Börner et al. (2010), Bowman et al. (2012), Assunção et al. (2013), Nepstad et al. (2014), Silva et al. (2019a, 2019b), and Koch et al. (2019).

Regarding the role of technical change in forest preservation, Villoria et al. (2014) suggest that technical change (productivity change) could lead to two opposite effects on forest preservation; higher deforestation as commercial activity is expanded, or lower deforestation due to less land-intensive production (input substitution). They argue that empirical work is needed to test which of these effects has prevailed. 
Filho et al. (2015), for example, investigated whether Brazil can increase food supply without increasing deforestation. They assert that conversion of low-yield pasture area to crop production could offset the production effect of reducing deforestation. To obtain these results, they used a Computable General Equilibrium (CGE) model of Brazil to model land use over 20 years. Although they conclude that improved technology could provide the amount produced by deforestation, it is almost certain that increased crop productivity would lead to deforestation, as well, absent some policy restrictions to prevent it.

Koch et al. (2019) study the effect of a policy to reduce deforestation on land use, crop yields and livestock stocking rate in a subset of municipalities in the Amazon subjected to a forest protection policy. They concluded that the policy would induce increases in the livestock stocking rate and a substitution of other inputs for land in these municipalities.

There are several recent studies of productivity of Brazilian agriculture. Bragagnolo et al. (2010) estimate Total Factor Productivity (TFP) for Brazilian agriculture using a panel of municipalities and agricultural census data (1975, 1985, 1995 and 2006). They estimated a translog production function to obtain the TFP and its several components including technical change. They found an average annual technical progress of around 3.1\%. Using their estimates of state-level average technical progress, we find the simple average rate of technical progress in the subset of states with municipalities in the "arc of deforestation" was around $6.7 \%$, ranging from $3.9 \%$ in Maranhão to $10.2 \%$ in Roraima.

Gasques and Conceicao (1997), Gasques et al. (2004), Gasques et al. (2008) and Fuglie (2010) have all previously measured agricultural TFP rates higher than 3\% for Brazil. Gasques et al. (2014) argue that a favorable international scenario, public research, and credit availability had important roles in these results. Rada and Valdes (2012) also found gains in TFP, mainly 
driven by technical change, at an annual rate of about $4 \%$ for recent decades. Mendes et al. (2009) and Trindade and Fulginiti (2015) measured lower TFP growth rates, 1\% for 1985-2004 and 2\% for 1969-2009, respectively. Gomes and Braga (2008) investigated factors associated with agricultural TFP in the Legal Amazon using state level data. They found that infrastructure and credit made available by a regional institution to promote growth (Fundo Constitutional de Financiamentos do Norte) contributed to higher TFP rates. None of these studies considered the relationship between agricultural TFP and $\mathrm{CO}_{2}$ from deforestation.

The harmful environmental effects of the production of goods have been studied using directional output distance functions with two kinds of outputs: undesirable (e.g., pollution) and desirable (e.g., production). Chung et al. (1997) argue that rates of productivity change are biased when estimated using conventional methods that do not consider harmful byproduct effects on the environment. Only a few studies have included undesirable outputs to evaluate productivity change in agriculture, as we do here, for example, Rezek and Perrin (2004), Färe, et al. (2006) and Kabata (2011) for the United States and Flavigna, et al. (2013) for Italy.

\section{THE MODEL}

In this article, we seek to estimate the rate and biases of technical change for agricultural production in the Brazilian Amazon. Figure 2 illustrates the production possibilities structure we propose, in this case for a single good output such as agriculture (vertical axis) and on the horizontal axis a single undesirable (or "bad") output such as $\mathrm{CO}_{2}$ emissions. Because direct measures of $\mathrm{CO}_{2}$ emissions do not exist, in this study we use deforestation as a proxy for $\mathrm{CO}_{2}$ emissions from land use change, which constitute the most important component of total greenhouse gas emissions in this region. For an undesirable output $b$ that is not freely disposable, 
the production possibilities frontier (PPF) exhibits an upward-sloping region where it is not possible to reduce the bad output $\left(\mathrm{CO}_{2}\right.$ emissions from deforestation) without also reducing some of the desirable output. Here we interpret a rightward movement along the horizontal axis as an increase in emissions, and a leftward movement as either a decrease in emissions or an increase in $\mathrm{CO}_{2}$ sequestration. This is a logical characterization of the agriculture/ $\mathrm{CO}_{2}$ technology in the Amazon.

Technical change is represented in Figure 2 by a shift in the frontier from the solid line to the dashed line. This outward shift of the production possibility frontier represents a progressive technical change, allowing both more agriculture and less $\mathrm{CO}_{2}$ emissions than previously attainable from the given set of inputs. A bias in technical change is revealed here by a change in the marginal rate of transformation (MRT) along a directional line segment such as BC. In the case illustrated, the marginal rate of transformation in terms of the amount of good output $y$ foregone to reduce a unit of bad output $b$ has increased. This is described as a technical change bias toward good output $y$ and away from bad output $b$, indicating that it is becoming relatively more expensive to sequester a unit of $\mathrm{CO}_{2}$. Generalizing the two-output representation of technology in Figure 2, in this study we represent the municipality-level agricultural technology of this region with a directional distance function relating three desirable outputs (timber, grains, and livestock), one undesirable output ( $\mathrm{CO}_{2}$ emissions); and three inputs (labor, capital and land).

We estimate the frontier of this production set with a directional distance function. Several previous studies have used directional distance functions to represent technologies that include the joint production of both desirable and undesirable outputs: Färe et al. (2005); Chung, et al. (1997); Färe, et al. (2006); Macpherson, et al. (2010). Our results will reveal that the PPF has 
shifted outward (progressive technical change) and that the slope has increased due to technical change (a bias toward agriculture).

The agricultural production technology uses inputs $\boldsymbol{x} \in \mathfrak{R}_{+}^{S}$ to produce outputs $\boldsymbol{u} \in \mathfrak{R}_{+}^{P}$. Some outputs $\boldsymbol{y} \in \mathfrak{R}_{+}^{M}$, are desirable (such as grain, livestock and timber production), and some outputs $\boldsymbol{b} \in \mathfrak{R}_{+}^{R}$, are undesirable $\left(\mathrm{CO}_{2}\right)$. We characterize the production technology using a directional distance function:

$$
\vec{D}_{o}\left(\boldsymbol{x}, \boldsymbol{y}, \boldsymbol{b}, t ; \boldsymbol{g}_{\boldsymbol{y}}, \boldsymbol{g}_{\boldsymbol{b}}\right)=\max \left\{\alpha:\left(\boldsymbol{y}+\alpha \boldsymbol{g}_{\boldsymbol{y}}, \boldsymbol{b}-\alpha \boldsymbol{g}_{\boldsymbol{b}}\right) \in P(\boldsymbol{x})\right\}
$$

where $\boldsymbol{g}_{\boldsymbol{y}}$ and $\boldsymbol{g}_{\boldsymbol{b}}$ constitute the directional vector $\boldsymbol{g}=\left(\boldsymbol{g}_{\boldsymbol{y}},-\boldsymbol{g}_{\boldsymbol{b}}\right)$ and subscripts $k=$ $(1,2, \ldots, N)$ representing observed units and $t=(1,2, \ldots, T)$ representing years are dropped for simplicity. This directional distance function defines the frontier of an output possibility set at time $t, P(\boldsymbol{x}, t)$. On the frontier itself, the value of the frontier function (1) is zero, determined in our case by a functional estimation of $P(\boldsymbol{x})$ that approximates the frontier determined by inputoutput bundles from the best performing units. For all observations inside the frontier the directional distance function is positive.

In general, the directional distance function is non-negative in $(\boldsymbol{y}, \boldsymbol{b})$, non-increasing and strongly disposable in $\boldsymbol{y}$, non-decreasing in $\boldsymbol{b}$, weakly disposable, and concave in $(\boldsymbol{y}, \boldsymbol{b})$. It also satisfies the translation property:

$$
\vec{D}_{o}\left(\boldsymbol{x}, \boldsymbol{y}+\alpha \boldsymbol{g}_{\boldsymbol{y}}, \boldsymbol{b}-\alpha \boldsymbol{g}_{\boldsymbol{b}}, t ; \boldsymbol{g}_{\boldsymbol{y}},-\boldsymbol{g}_{\boldsymbol{b}}\right)=\vec{D}_{o}\left(\boldsymbol{x}, \boldsymbol{y}, \boldsymbol{b}, t ; \boldsymbol{g}_{\boldsymbol{y}},-\boldsymbol{g}_{\boldsymbol{b}}\right)-\alpha, \quad \alpha \in \Re
$$

which states that increasing desirable outputs by $\alpha \boldsymbol{g}_{\boldsymbol{y}}$ and simultaneously decreasing undesirable outputs by $-\alpha \boldsymbol{g}_{\boldsymbol{b}}$ is equivalent to subtracting the translation factor $\alpha$ from the original directional distance function. 
Figure 2 illustrates this directional distance function for the case of one desirable output $y$ and one undesirable output $b$ and a fixed bundle of inputs, given a directional vector $\boldsymbol{g}=$ $\left(g_{y},-g_{b}\right)=(1,-1)$. The positive slope of the frontier (the locus of points for which $\vec{D}_{o}=0$ ) indicates that the undesirable good $b$ is weakly disposable, which means that for given input levels it is costly to dispose of $b$ in terms of desirable good $y$ that must be given up. The distance of observation $k^{t}$ from the frontier is represented as a projection from point A along vector $\boldsymbol{g}=$ $(1,-1)$ to point $\mathrm{B}$. The directional output distance function measures this distance as $\alpha$, the maximum feasible simultaneous expansion of $y$ and contraction of $b$, with distance $\alpha$ measured in multiples of the vector $\boldsymbol{g}=\left(g_{y},-g_{b}\right)$.

\section{[Figure 2]}

\subsection{Parameters characterizing technical change}

Traditionally, technical change has been characterized by two kinds of parameters: a rate of technical change and biases of technical change toward/against individual outputs and inputs. Here, an outward shift of the frontier represents a technical change of positive (progressive) rate, while an inward shift indicates a negative (regressive) rate. A pair-wise Hicks neutral ${ }^{1}$ technical change is implied if the MRT is the same at point $\mathrm{B}$ and point $\mathrm{C}$ along the projection of the original observation between the two frontiers. If between points B and C the MRT changes, technical change is biased. In that case, technical change has altered the frontier tradeoff (the MRT) between good and bad output in the projection of observation $k^{t}$ along vector $\boldsymbol{g}=$ $\left(g_{y},-g_{b}\right)$. In the case illustrated in figure 2, technological change is biased toward $y$, in accord

\footnotetext{
${ }^{1}$ We use the Blackorby et al. (1976) interpretation of Hicks neutral technical change. Specifically we have adapted their implicit Hicks neutrality (IHN) concept to output space with desirable and undesirable outputs.
} 
with the notion of implicit Hicksian neutrality in Blackorby, et al. (1976). Given the algebraic specification of the distance function that we will use, both the rate and the bias of the shift in the frontier can differ depending on the location of observation $k^{t}$ in $P(\boldsymbol{x})$ and depending on the directional vector along which the data point is projected. We estimate both the rate and bias of technical change at the data points for each municipality, as described below.

\subsection{Primal output-based directional measure of the rate of technical change}

We measure the rate of technical change following the strategy developed by Färe and Karagiannis (2014). The total differential of the distance function is

$$
-\left(\nabla_{b} \vec{D}_{o}\right)^{\prime} g_{b} d \alpha+\left(\nabla_{y} \vec{D}_{o}\right)^{\prime} g_{y} d \alpha+\frac{\partial \vec{D}_{o}}{\partial t} d t+\nabla_{x} \vec{D}_{o} d x=0
$$

Specifying $d x=0$, imposing the translation property as $-\left(\nabla_{b} \vec{D}_{o}\right)^{\prime} g_{b}+\left(\nabla_{y} \vec{D}_{o}\right)^{\prime} g_{y}=-1$ and solving for the rate of technical change, $d \alpha / d t$ :

$$
\frac{d \alpha}{d t}=\frac{\partial \vec{D}_{o}}{\partial t}
$$

The rate of technical change is thus measured as the common number of times the desirable output and the undesirable output vectors $\left(g_{y}\right.$ and $\left.g_{b}\right)$ can be added to the desirable output and subtracted from the undesirable output as a result of technological change, starting at a given output plan on the original $P P F$. In figure 2 it is represented by the length of the segment $B C$. 


\subsection{Primal output-based directional measure of the bias of technical change}

We use a primal definition of Hicksian bias (Fulginiti, 2010) between a desirable output $y_{m}$ and an undesirable output $b$, defined as the change in the MRT along the projection ray $\boldsymbol{g}=$ $\left(g_{y_{m}},-g_{b}\right):$

$$
B_{y_{m}, b}(\boldsymbol{y}, \boldsymbol{b}, \boldsymbol{x}, t) \equiv \frac{\partial \ln \left(M R T_{y_{m}, b}\right)}{\partial t}
$$

where $M R T_{y_{m}, b}$ is defined as the ratio of $\partial \vec{D}_{o} / \partial b$ to $\partial \vec{D}_{o} / \partial y_{m} . B_{y_{m}, b}$ measures the Hicksian pair-wise bias in technical change as a change in the slope of the production possibility frontier along the directional ray $\boldsymbol{g}=\left(g_{y_{m}},-g_{b}\right) . B_{y_{m}, b}>0$ indicates that technical change is biased towards the production of desirable output $y_{m}$ relative to undesirable output $b$, i.e., technical change has led to an increase in the cost of reducing a unit of undesirable output $b$, in terms of desirable output $y_{m}$ given up. $B_{y_{m}, b}<0$ indicates that technical change is biased against production of desirable output $y_{m}$ relative to undesirable output $b$.

\section{THE APPLICATION}

Our sample of municipalities for analysis is selected from the 574 municipalities in the nine-state region we have identified as constituting the arc of deforestation. We first calculated total deforestation as a proxy for $\mathrm{CO}_{2}$ emissions by municipality, over the period 2001 to 2015 , using data from the National Institute for Space Research (INPE/PRODES, 2017). Because many of the smaller municipalities registered no forest or anomalous levels of deforestation, we selected 
for this study the 287 municipalities with deforestation above the median of 13,000 ha, which represent $94 \%$ of deforestation in this area. ${ }^{2}$

Annual data on desirable outputs and inputs at the municipal level for the period 2003-2015 are from the Municipal Agricultural Production (in Portuguese Produção Agrícola Municipal PAM) survey ${ }^{3}$ conducted by the Brazilian Institute of Geography and Statistics (IBGE, 2017). We obtained information on grains, livestock and timber production. Grain production is measured as the sum of corn and soybean production (in tons per year). Timber is measured in cubic meters of logged wood per year. Livestock production is measured in thousand liters of milk produced per year, given that data on cattle sold is not available on an annual basis.

Descriptive statistics are in table 1.

Because direct measures of $\mathrm{CO}_{2}$ emissions from the Brazilian Amazon at municipal scale do not exist, in this study we use deforestation as a proxy for $\mathrm{CO}_{2}$ emissions from land use change. Although the emissions from deforestation depend on the density and type of forest, we use the average emission rate of 132.2 tons of carbon (Brazilian Ministry of Environment (MMA), 2011; Amazon Fund, 2015) ${ }^{4}$ per hectare of forest preserved, which is used by the government of Brazil in their REDD+ contracts with Norway, Germany, Petrobras and others. Deforestation by municipality, measured in hectares per year, was obtained from the National Institute for Space Research (INPE/PRODES, 2017). Margulis (2004) suggests that deforestation of a given plot might occur over three years, and be detected only in the third year of the process, depending on

\footnotetext{
${ }^{2}$ We also completed the analysis for the entire set of 574 municipalities and for a set of 313 municipalities with deforestation above 10,000 ha, with no substantive change in our conclusions.

${ }^{3}$ Agricultural Census data was available for 1995/96 and 2006, while deforestation at municipal level was only available from 2000 to 2016 on January of 2017.

${ }^{4}$ The Amazon Fund (2015) raises funds to preserve the forest using this carbon content based on the Technical Committee of the Amazon Fund (CTFA), but states that it is a conservative measure considering that the carbon content in the Amazon Forest ranges from 130 tons of Carbon/ha to 320 tons of Carbon/ha.
} 
the process of deforestation used. It is possible that agricultural activities would be occurring during this process with revenue from both agriculture and timber sales during this period. This leads us to follow Margulis and measure deforestation for a given year as the average of the current and previous two years.

Municipalities in the state of Pará and Mato Grosso have the largest average deforestation, 6,595 and 5,951 hectares, respectively. Grain production is largest in municipalities in the state of Mato Grosso averaging 273,037 tons of grains per year. Municipalities in the state of Rondônia have the largest average livestock production, 13,337 thousand liters of milk. Municipalities in the state of Pará have the largest average production of timber, $83,972 \mathrm{~m}^{3}$.

\section{[Table 1]}

We were able to obtain information on three inputs, all from IBGE. We measure labor as the population in the municipality. Rural population is more than $70 \%$ in about $75 \%$ of the municipalities. Agricultural area is measured in hectares, obtained by subtracting forest area from the total area of the municipality. Capital is represented by stock of livestock, in number of head. Following Färe et al. (2005), we normalized all these variables, dividing by their means ${ }^{5}$. In addition to these inputs we add a time trend to capture exogenous technical change.

\subsection{Empirical estimation}

We specify the distance function (Eq. 1) as a quadratic flexible functional form, with the subscript $i=(1,2, \ldots, N)$ representing municipalities and subscript $t=(1,2, \ldots, \mathrm{T})$ for periods (subscripts $t$ are dropped here, for simplicity):

\footnotetext{
${ }^{5}$ For a hypothetical municipality that uses mean inputs and produces mean outputs, the input and output variables would be $(x, y, b)=(1,1,-1)$.
} 


$$
\begin{aligned}
\vec{D}_{o, i}\left(\boldsymbol{x}_{\boldsymbol{i}}, \boldsymbol{y}_{\boldsymbol{i}}, b_{i}, ; t, 1,-1\right)=\gamma_{0}+\sum_{s=1}^{3} \gamma_{k} x_{s i}+\theta_{1} b_{i}+\sum_{m=1}^{3} \beta_{m} y_{m i}+\frac{1}{2} \sum_{s=1}^{3} \sum_{l=1}^{3} \gamma_{k l} x_{s i} x_{l i} \\
+\frac{1}{2} \sum_{m=1}^{3} \sum_{n=1}^{3} \beta_{m n} y_{m i} y_{n i}+\frac{1}{2} \theta_{11} b_{i}^{2}+\sum_{m=1}^{3} \sum_{s=1}^{3} \delta_{m s} x_{k i} y_{m i}+\sum_{s=1}^{3} \varphi_{s} x_{s i} b_{i} \\
+\sum_{m=1}^{3} \mu_{m} y_{m i} b_{i}+v_{1} t+\frac{1}{2} v_{11} t^{2}+\sum_{s=1}^{3} \vartheta_{s 1} x_{s i} t+\sum_{m=1}^{3} \eta_{m} y_{m i} t+\lambda_{1} t b_{i}
\end{aligned}
$$

where $x_{k i}$ are labor, capital, and area, $y_{m i}$ are timber, livestock and grains, and $b_{i}$ is deforestation as proxy for $\mathrm{CO} 2$ emissions, $t$ is technical change measured as years, and $\gamma^{\prime} s, \beta$ 's, $\theta^{\prime} s, \delta$ 's, $\varphi^{\prime} s$, $v$ 's, $\vartheta$ 's , $\eta^{\prime} s, \mu$ 's and $\lambda_{1}$ are parameters to be estimated. The intercept is a constant term plus municipality fixed effects (dummies). We use the directional vector $=\left(\boldsymbol{g}_{\boldsymbol{y}},-g_{b}\right)=(\mathbf{1},-1)$, representing a simultaneous expansion in desirable outputs and contraction of undesirable output, where 1 is a $1 \times 3$ unit vector. The symmetry and translation properties in outputs and inputs are imposed before estimation, requiring the following restrictions:

$$
\begin{aligned}
& \sum_{m=1}^{3} \beta_{m}-\theta_{1}=-1 ; \sum_{n=1}^{3} \beta_{m n}-\mu_{m}=0 ; \theta_{11}-\sum_{m=1}^{3} \mu_{m}=0 ; \sum_{m=1}^{3} \delta_{m s}-\varphi_{s}=0 \\
& \sum_{m=1}^{3} \eta_{m}-\lambda_{1}=0 ; m=1,2 \text { and } 3 ; s=1,2 \text { and } 3 ; \beta_{m n}=\beta_{n m}
\end{aligned}
$$

We estimated equation (5) after imposing the translation property in (1a) that results in transformation of outputs and of the left hand side, at $\vec{D}_{o, i}\left(\boldsymbol{x}_{\boldsymbol{i}}, \boldsymbol{y}_{\boldsymbol{i}}, b_{i}, ; t, \mathbf{1},-1\right)=0$, as

$$
-\alpha_{i}=\vec{D}_{o_{i}}\left(x_{i}, y_{i}+\alpha_{i}, b_{i}-\alpha_{i} ; \mathbf{1},-1\right)+\epsilon_{i}
$$

where $\alpha_{i}$ is the translation factor and $\epsilon_{i}$ is an error term. The quadratic flexible functional form with symmetry and translation properties imposed is estimated as 


$$
\begin{aligned}
& -b_{i}=\gamma_{0}+\sum_{s=1}^{3} \gamma_{s} x_{k i}+\theta_{1} b_{i}^{\prime}+\sum_{m=1}^{3} \beta_{m} y_{m}^{\prime}+\frac{1}{2} \sum_{s=1}^{3} \sum_{l=1}^{3} \gamma_{s l} x_{s i} x_{l i} \\
& +\frac{1}{2} \sum_{m=1}^{3} \sum_{n=1}^{3} \beta_{m n} y_{m i}^{\prime} y_{n i}^{\prime}+\frac{1}{2} \theta_{11} b_{i}^{\prime 2}+\sum_{m}^{3} \sum_{s=1}^{3} \delta_{m s} x_{s i} y_{m i}^{\prime}+\sum_{s=1}^{3} \varphi_{s} x_{s i} b_{i}^{\prime} \\
& \quad+\sum_{m=1}^{3} \mu_{m} y_{m i}^{\prime} b_{i}^{\prime}+v_{1} t+\frac{1}{2} v_{11} t^{2}+\sum_{s=1}^{3} \vartheta_{s 1} x_{s i} t+\sum_{m=1}^{3} \eta_{m} y_{m i}^{\prime} t+\lambda_{1} t b_{i}^{\prime}+\epsilon_{i}
\end{aligned}
$$

where $y_{1 i}^{\prime}=y_{1 i}+\alpha_{i}, b_{i}^{\prime}=b_{i}-\alpha_{i}$. In our case we chose $\alpha_{i}=b_{i}{ }^{6}$, so the parameters

associated with $b_{i}$ are recovered after estimation using the translation property restrictions. We calculate estimated technical change following equation (3), as

$$
\frac{\partial \vec{D}_{o}}{\partial t}=v_{1}+v_{11} t+\sum_{s=1}^{3} \vartheta_{s 1} x_{s i}+\sum_{m}^{3} \eta_{m} y_{m i}+\lambda_{1} b_{i}
$$

The biases of technical change are calculated using equation (4) as

$$
B_{y_{m i}, b_{i}}\left(y_{m i}, b_{i}, x, t\right) \equiv\left[\frac{\lambda_{1}}{\vec{D}_{b_{i}}}-\frac{\eta_{m}}{\vec{D}_{y_{m i}}}\right]
$$

where $\vec{D}_{b_{i}}$ and $\vec{D}_{y_{m i}}$ represent the first derivatives of the directional distance function for municipality $i$ with respect to the undesirable and a desirable output, respectively.

Our selection of the directional vector $(1,1,1,-1)$ for measuring technical change warrants some comment. First, recall that our output levels have been normalized by dividing by their means, so that one unit of distance is equivalent to $100 \%$ of the mean of each variable. Recall also that we measure the rate of technical change at each observation (equation 8) as the change

\footnotetext{
${ }^{6}$ The factor $\alpha_{i}$ used to impose the translation property of the directional distance function is chosen by the researcher and most studies have chosen one of the outputs. In this article, we have used the undesirable output but we have also estimated Eq. (6) considering $\alpha_{i}=y_{1 i}$. Results are quite consistent with those with $\alpha_{i}=b_{\text {i }}$.
} 
in distance evaluated for that municipality. Thus, if the change in distance is 0.10 , this implies that the production frontier has shifted outward along the vector $(1,1,1,-1)$ with each agricultural output increasing by $10 \%$ of its mean and deforestation decreasing by $10 \%$ of its mean. The $10 \%$ is thus a measure of the change in the entire bundle of outputs that is made possible by technical change, which itself is a measure of welfare that was pioneered by Allais, Debreu and others.

This directional measure is not only appealing as an economic concept, it is also completely consistent with the traditional measures of productivity change that consider a single aggregated output. This traditional approach would also measure a $10 \%$ productivity change if all subcategories of output were to increase by $10 \%$ for given levels of input.

We first use Corrected Ordinary Least Squares (COLS) to provide starting values for the parameters in the Maximum Likelihood Estimation (MLE) procedure. For the MLE estimation, the error term in equation (7) is specified as $\epsilon_{i}=u_{i}-z_{i}$, where $u_{i}$ represents the standard error term and $z_{i}$ captures the distance from the frontier, also interpreted as a measure of the inefficiency of observation $i$. We assume a half-normal distribution for $z_{i} \sim N^{+}\left(0, \sigma_{z}^{2}\right)$, as described in Kumbhakar, Wang, and Horncastle (2015). The estimation was done using Stata 14 following the command sfmodel suggested by Kumbhakar, et al. (2015) and sfcross suggested by Belotti, et al. (2012).

\section{RESULTS AND DISCUSSION}

We estimated the quadratic specification for the directional distance function in equation (7) using a frontier MLE approach described above ${ }^{7}$. Parameter estimates for the first step COLS

\footnotetext{
${ }^{7}$ A Likelihood Ratio test of 35.09 indicates that MLE estimates with a half-normal distribution for the one-sided error term are superior to the COLS estimates (the one percent critical value is 5.4). We also utilized the GMM method and found the results to be similar. These results can be obtained from the authors upon request.
} 
and the MLE are shown in table A1 in Appendix A. The MLE estimation has 30 statistically significant parameters out of 36 (excluding municipality dummies).

An estimate of the distance of each municipality from the frontier is obtained from equation (7), and is interpreted as a measure of inefficiency. The average distance estimated for the region was 0.19 . This means that for the average municipality, agricultural outputs (grains, timber and livestock) could be expanded by $19 \%$ each while simultaneously decreasing $\mathrm{CO}_{2}$ by $19 \%$. We acknowledge, however, that to the extent that the quality of resources is not homogeneous across municipalities, it may not be possible to close all of these efficiency gaps.

The estimated rate and biases of technical change vary over the production space depending on the level of inputs and outputs for individual municipalities at each point in time. We evaluated the estimated annual rate and biases for each observation, then averaged those estimates. The overall average annual rate of technical change estimated for this region during the period $2003-2015$ is $4.93 \%$ (see table 2). This means that on average for given levels of inputs, technical change has shifted the frontier outward, allowing municipalities to expand agricultural outputs (grains, timber and livestock) by around $4.93 \%$ while simultaneously contracting $\mathrm{CO}_{2}$ emissions (deforestation) by $4.93 \% .{ }^{8}$ Average estimates for each year vary from 0.042 to 0.061 , following a slightly U-shaped pattern as revealed in Figure 3 . At the municipality-level, estimates of this rate vary across space, as illustrated in Figure 4.

Other studies reporting rates of technological change in Brazilian agriculture have not considered deforestation or emissions, and analyze the whole country except for the Bragagnolo et al. (2010), who provide estimates by state. Bragagnolo's estimates of the rate, for an earlier

\footnotetext{
${ }^{8}$ Estimated average rates of technical change for the entire set of 574 municipalities is 0.045 and for the 313 municipalities with deforestation above 10.000 hectares is 0.048 , compared with 0.049 for the sample in this study.
} 
period (1975-2006), averaged 3.1\% for the country, but for the states in which the municipios of our study are located, the simple average estimate of the rate was $6.7 \%$. Gasques and Conceicao (1997), Gasques et al. (2004), Gasques et al. (2008), Fuglie (2010) and Rada and Valdes (2012) all measured country-wide rates exceeding 3\%, but Trindade and Fulginiti (2015) estimated rates of only $1 \%$ for $1985-2004$ and $2 \%$ for 1969-2009. Gomes and Braga (2008) investigated factors associated with agricultural TFP in the Legal Amazon using state level data and found that infrastructure contributed to higher rates.

\section{[Table 2]}

[Figure 3]

\section{[Figure 4]}

Our primary interest for this study is in the biases of technical change between agricultural production and $\mathrm{CO}_{2}$ emissions, because they indicate changes in trade-offs due to technical change. We evaluate this issue by estimating Hicksian pairwise technical change biases as defined in equation (4) and equation (9). Our results indicate that municipalities in the "arc of deforestation" have experienced technical change that is biased toward each agricultural output and against $\mathrm{CO}_{2}$ emissions. This means that as a result of technical change, for a given level of efficiency, less $\mathrm{CO}_{2}$ emissions from deforestation is now necessary to increase a unit of agricultural output. Expressed as the inverse, it means that the opportunity cost to farmers of reducing $\mathrm{CO}_{2}$ emissions by one unit has increased in terms of agricultural output foregone. An interpretation of this is that the cost to farmers of legal restrictions intended to reduce $\mathrm{CO}_{2} /$ deforestation has increased, an issue that we discuss below.

[Figure 5] 
From equation (8), the estimate of parameter $\lambda_{1},+0.017$, indicates that the estimate of the rate of technical change is higher in areas with more emissions from deforestation, and the positive values of coefficients for grain, livestock and timber indicate that the rate of technical change is also higher in areas with more of each of the agricultural outputs.

For each of the desirable outputs we evaluate pairwise technical change biases relative to $\mathrm{CO}_{2}$ emissions from deforestation using equation (9). As indicated earlier, a pairwise bias in favor of, say grains, relative to $\mathrm{CO}_{2}$ would be reflected by a steeper $\mathrm{MRT}_{\mathrm{t}+1}$ in Figure 2. To evaluate whether technical change has on average been biased toward grains and against $\mathrm{CO}_{2}$ from deforestation, we evaluate $B_{y_{1}, b_{1}}$ at each observation using equation (9), then calculate the average across municipalities. We proceed in the same manner to estimate average technical biases with respect to timber and livestock. Using the maximum likelihood estimates (MLE in Table 2), we find that the average bias for grains relative to $\mathrm{CO}_{2}$ is $B_{y_{1}, b_{1}}=0.15$, for timber relative to $\mathrm{CO}_{2}$ is $B_{y_{3}, b_{1}}=0.11$ and for milk relative to $\mathrm{CO}_{2}$ is $B_{y_{2}, b_{1}}=0.17$. These estimates indicate that as a result of bias in technical change, more of each of these agricultural outputs must be foregone to decrease one unit of $\mathrm{CO}_{2}$ emission from deforestation, as illustrated by the increased slope of the MRT in Figure 2.

In 2007, the Brazilian government identified a list of priority municipalities with high levels of deforestation and high rates of growth of agricultural output, where strict monitoring would take place. These 40 municipalities, clustered in the states of Pará and Mato Grosso, are all included in our sample. Our results show that the average rate of technical change in the priority municipalities was $10.3 \%$, significantly higher than the $3.8 \%$ in the rest of the municipalities in these states (the null hypothesis of no difference in these means was rejected at the $1 \%$ level). Koch et al. (2019) using a diff-in-diff approach study the impact of this monitoring policy on 
crop yields and livestock stocking rates in priority municipalities versus others. They conclude that this policy resulted in substitution of land by other inputs and increased livestock stocking rates in priority municipalities; results that do not contradict our broader multifactor productivity estimates for these municipalities.

Brazilian policies to reduce $\mathrm{CO}_{2}$ emissions by controlling deforestation, such as the 2004 Action Plan for Deforestation Prevention and Control in the Legal Amazon ${ }^{9}$ and others mentioned below, may be related to these results in two ways. First, these programs have focused attention on the tradeoff between deforestation and agricultural production, providing incentives and enforcement to reduce deforestation and therefore emissions. These incentives or penalties would increase the slope of the iso-revenue line (not shown in Figure 2) that agents would presumably use as a target to adjust the MRT to the profit-maximizing point on the production possibilities frontier in Figure 2. The policies would thus lead us to observe municipalities with less deforestation (and emissions) than was profitable (reductions in both desirable and undesirable output along the transformation frontier in the vicinity of $\mathrm{B}$ and $\mathrm{C}$ in figure 2). Second, the policies may have also affected the nature of technical change by inducing development and adoption of innovations that allowed both yield increases and reduced deforestation and therefore emissions (Nepstad et al., 2014). Therefore the relationship between policies, their impacts on behavior, and their impact on the nature of technical change, although important, cannot be entirely disentangled. In this analysis we do not examine any explicit impact of policies on the technology set itself, given the extended period of time required for such an impact to occur.

\footnotetext{
${ }^{9}$ Plano de Ação para a Prevenção e Controle do Desmatamento na Amazônia Legal - PPCDAm found at http://www.mma.gov.br/florestas/controle-e-preven $\% \mathrm{C} 3 \% \mathrm{~A} 7 \% \mathrm{C} 3 \% \mathrm{~A} 30$-do-desmatamento/plano-dea $\%$ C3\%A7\%C3\%A3o-para-amaz $\%$ C3\%B4nia-ppcdam
} 
Among the other policies mentioned above are the Soy Moratorium (SoyM) in 2006, and the Cattle Agreement in 2010, which constituted obstacles to deforestation and the concomitant reductions in emissions despite the fact that they are voluntary (Nesptad et al., 2014; Gibbs et al., 2015). The enforcement of newer regulations such as the Brazilian Forest Code (FC), the Rural Environmental Registry of private property (CAR), and surveillance by the Brazilian Institute of the Environment and Renewable Natural Resources (IBAMA), have been shown to have positive impacts as deforestation and therefore to be effective emission control mechanisms (Gibbs et al., 2015; Soares-Filho et al., 2014; Hargrave and Kis-Katos, 2013). The impact of these regulations on the rate and bias of technical change has not been explicitly studied in this research, but we speculate that the intensification measured by the bias in technical change might have been, in part, a result.

The Brazilian government has also invested in infrastructure, public research and extension, and has promoted agricultural production via increased credit availability (Gomes and Braga (2008); Gasques et al. (2014)). From 1999 to 2009, credit availability through the Program to Support Family Farms (PRONAF) $)^{10}$ has increased, on average, at a rate of $24 \%$ annually for the states considered in this article. The total credit made available by the government to this region increased six-fold between 2001 and 2009. These incentives would appear to favor increased agricultural production, presumably to some extent at the cost of higher $\mathrm{CO}_{2}$ emissions.

\footnotetext{
${ }^{10}$ Programa Nacional de Fortalecimento da Agricultura Familiar. This information is for all municipalities in the Legal Amazon region and can be found at http://www.mda.gov.br/sitemda/pagina/acompanhe-

a $\%$ C $3 \%$ A $7 \%$ C $3 \%$ B 5 es-do-mda-e-incra
} 


\section{CONCLUSIONS}

In this article we evaluate whether the high measured rates of technical change reported in the literature for Brazilian Amazon agriculture remain high when $\mathrm{CO}_{2}$ emissions, considered as an undesirable output, are included in the estimation. We are more specifically interested in the nature of the biases in technical change, to determine whether innovations have made it less or more costly to reduce $\mathrm{CO}_{2}$ emissions from deforestation. Our analysis of these issues is based on a sample of 287 municipalities in the "arc of deforestation" in Brazil over the period 2003-2015. We estimated an aggregate municipality-level technology using a directional output distance function with data on grains, livestock and timber production from IBGE and $\mathrm{CO}_{2}$ emissions from deforested area from INPE. The directional distance function was specified as a flexible quadratic form and estimated using a stochastic frontier approach.

Our results reveal that the rate of technical change (the percentage increase in agricultural outputs and decrease in emissions achievable while holding inputs constant) averaged about $4.9 \%$ per year across these municipalities during the period from 2003 to 2015 . These estimates of technical change are as high or higher than other estimates for Brazil that have ranged between $1 \%$ to $4 \%$, even though in our case we included reduction of emissions in the analysis.

The most significant of our results are that technical change was biased toward agricultural production relative to emissions indicating a change in the marginal rate of transformation along the production possibility frontier between $\mathrm{CO}_{2}$ emissions and agricultural outputs. This possibility has not been examined before, and it indicates that for given levels of inputs, more agricultural production must be foregone per unit of $\mathrm{CO}_{2}$ sequestered in the forest. For future agricultural/environmental policies, these results imply that incentives for decreasing deforestation-related $\mathrm{CO}_{2}$ emissions will need to increase well above the current $\$ 5 / \mathrm{t}$ in Brazil's 
$\mathrm{REDD}^{+}$agreements, and will need to continue to increase if preservation of the forest is to be financially attractive relative to agricultural production.

The observed rates of deforestation in this region were decreasing during the period of analysis. We take this as indirect evidence of the success of Brazilian policies during this period intended to reduce deforestation and therefore emissions. Our results show that meanwhile the technology was changing in such a way as to make it more ever expensive to reduce deforestation. However, news media have reported recently that deforestation in 2016 was higher than in 2015, the last year of our study. Deforestation in the state of Mato Grosso for example, increased by $190 \%$ during the first months of 2016 compared to $2015^{11}$. In fact there has been an increase of $58 \%$ in the annual deforestation rate in the last four years, from 6.2 thousand $\mathrm{km}^{2}$ in 2015 to 9.8 thousand $\mathrm{km}^{2}$ in $2019^{12}$. Our interpretation is that during the early years of the century, policies were effectively inhibiting deforestation, despite the increasing incentives to deforest because of the nature of technical change. More recent relaxation of the enforcement of the policies has allowed the accumulating deforestation incentive to be expressed as a catching-up of the rate of deforestation consistent with this technological change. When combined with the hotter, drier conditions accompanying climate change, this has resulted in a burst of deforestation. Clearly these events are evidence that the REDD+ payments of $\$ 5$ per ton of $\mathrm{CO}_{2}$ preserved are no longer high enough to reduce emissions, relative to the growing value of the agricultural production foregone.

\footnotetext{
${ }^{11} \mathrm{http}: /$ g1.globo.com/mato-grosso/noticia/2016/05/desmatamento-da-amazonia-legal-aumenta-190-em-mt-dizimazon.html

${ }^{12}$ Information available at TerraBrasilis

(http://terrabrasilis.dpi.inpe.br/app/dashboard/deforestation/biomes/legal_amazon/rates).
} 


\section{REFERENCES}

Amazon Fund, 2015. Amazon Fund Activity Report 2015. The Brazilian Development Bank (BNDES), Ministry of Planning, Development and Management, and Ministry of the Environment.

Andersen, L. E. 2002. The dynamics of deforestation and economic growth in the Brazilian Amazon. Cambridge University Press.

Araujo, Claudio, Catherine Araujo Bonjean, Jean-Louis Combes, Pascale Combes Motel, and Eustaquio J. Reis. 2009. "Property rights and deforestation in the Brazilian Amazon." Ecological Economics 68, no. 8: 2461-2468.

Assunção, J., C. Gandour, and R. Rocha. 2013. "DETERring deforestation in the Brazilian Amazon: environmental monitoring and law enforcement". Climate Policy Initiative: PUCRio. Accessed in January 2017 at https://climatepolicyinitiative.org/wpcontent/uploads/2013/05/DETERring-Deforestation-in-the-Brazilian-Amazon-EnvironmentalMonitoring-and-Law-Enforcement-Technical-Paper.pdf.

Belotti, Federico and Daidone, Silvio and Ilardi, Giuseppe and Atella, Vincenzo, Stochastic Frontier Analysis Using Stata (September 13, 2012). CEIS Working Paper No. 251. Available at SSRN: https://ssrn.com/abstract=2145803 or http://dx.doi.org/10.2139/ssrn.2145803

Blackorby, C., C.A.K. Lovell, and M. Thursby. 1976. "Extended Hicks neutral technical change." The Economic Journal 86, December 1976: 845-852.

Börner, J., S. Wunder, S. Wertz-Kanounnikoff, M. R. Tito, L. Pereira, and N. Nascimento. 2010. "Direct conservation payments in the Brazilian Amazon: Scope and equity implications." Ecological Economics 69, no. 6: 1272-1282. 
Bowman, M. S., B. S. Soares-Filho, F. D. Merry, D. C. Nepstad, H. Rodrigues, and O. T. Almeida. 2012. "Persistence of cattle ranching in the Brazilian Amazon: a spatial analysis of the rationale for beef production." Land Use Policy 29, no. 3: 558-568.

Bragagnolo, Cassiano, Humberto FS Spolador, and G. S. C. Barros. 2010. "Regional brazilian agriculture TFP analysis: A stochastic frontier analysis approach." Revista Economia 11: 217-242.

Brazilian Institute of Geography and Statistics (IBGE). 2017. Municipal Agricultural Production (Producao Agricola Municipal). Accessed January, 2017 at http://www2.sidra.ibge.gov.br/bda/acervo/acervo9.asp? $=\mathrm{c} \& p=\mathrm{PA} \& \mathrm{z}=\mathrm{t} \& \mathrm{o}=11$.

Brazilian Ministry of Environment (MMA), 2011. Department of policies to tackle deforestation (DPCD) - Nota tecnica No. 22.

Cardille, J. A., and J. A. Foley. 2003. "Agricultural land-use change in Brazilian Amazonia between 1980 and 1995: Evidence from integrated satellite and census data." Remote Sensing of Environment 87, no. 4: 551-562.

Chung, Y. H., R. Färe, and S. Grosskopf. 1997. "Productivity and undesirable outputs: a directional distance function approach." Journal of Environmental Management 51, no. 3: 229-240.

Diaz, M. C.V., and S. Schwartzman. 2005. "Carbon offsets and land use in the Brazilian Amazon." Tropical deforestation and climate change: 9398.

Färe, Rolf, and Giannis Karagiannis. 2014. "Radial and directional measures of the rate of technical change." Journal of Economics 112, no. 2: 183-199.

Färe, Rolf, Shawna Grosskopf, Dong-Woon Noh, and William Weber. 2005. "Characteristics of a polluting technology: theory and practice." Journal of Econometrics 126, no. 2: 469-492. 
Färe, Rolf, Shawna Grosskopf, and William L. Weber. 2006. "Shadow prices and pollution costs in US agriculture." Ecological Economics 56, no. 1: 89-103.

Falavigna G., Manello A., Pavone S., (2013), Environmental efficiency, productivity and public funds: the case of the Italian agricultural industry, Agricultural Systems, 121:73-80, DOI: 10.1016/j.agsy.2013.07.003

Filho, J. B. S.F., L. Ribera, and M. Horridge. 2015 "Deforestation control and agricultural supply in Brazil." American Journal of Agricultural Economics 97, no. 2: 589-601.

Fuglie, K. O. 2010. "Total factor productivity in the global agricultural economy: Evidence from FAO data." The shifting patterns of agricultural production and productivity worldwide: pages 63-95. Iowa State University, The Midwest Agribusiness Trade Research and Information Center (MATRIC).

Fulginiti, Lilyan E. 2010. "Estimating Griliches' k-shifts." American Journal of Agricultural Economics 92, no. 1: 86-101.

Gasques, José Garcia, and Júnia Cristina PR da Conceição, 1997. "Crescimento e produtividade da agricultura brasileira." TEXTO PARA DISCUSSÃO No 502 - Institute of Applied Economic Research (IPEA).

Gasques, José Garcia, Eliana Teles Bastos, Mirian PR Bacchi, and Júnia CPR da Conceição, 2004. "Condicionantes da produtividade da agropecuária brasileira." Revista de Politica Agricola 13, no. 3: 73-90.

Gasques, José Garcia, Eliana Teles Bastos, Constanza Valdes, and Mirian Rumenos Piedade Bacchi. 2014. "Produtividade da agricultura: resultados para o Brasil e estados selecionados." Revista de Política Agrícola 23, no. 3: 87-98. 
Gasques, José Garcia, Eliana Teles Bastos, and Mirian R. Piedade Bacchi, 2008. "Produtividade e fontes de crescimento da agricultura brasileira." in Políticas de incentivo à inovação tecnológica. Available at

http://www.en.ipea.gov.br/agencia/images/stories/PDFs/livros/capitulo11_27.pdf

Gibbs, H. K., L. Rausch, J. Munger, I. Schelly, D. C. Morton, P. Noojipady, B. Soares-Filho, P. Barreto, L. Micol, and N. F. Walker. 2015. "Brazil's Soy Moratorium." Science 347, no. 6220: $377-378$.

Gomes, S. C., and M. J. Braga. 2008. "Determinantes da produtividade total dos fatores na Amazônia legal: uma aplicação de dados em painel." Amazônia: Ciência \& Desenvolvimento 3: 127-146.

Hargrave, Jorge, and Krisztina Kis-Katos. 2013. "Economic causes of deforestation in the Brazilian Amazon: a panel data analysis for the 2000s." Environmental and Resource Economics 54, no. 4: 471-494.

Kabata, Tshepelayi, 2011. "The U.S. agriculture greenhouse emissions and environmental performance." In Annual Meeting of the Agricultural Applied Economics Association. Pittsburg, Pennsylvania, pp. 24-26. Available at http://ageconsearch.umn.edu/bitstream/103427/2/Agecon\%20Search\%20_The $\% 20$ US\%20Ag riculture $\% 20$ Greenhouse $\% 20$ Emissions $\% 20$ and $\% 20$ Environmental\%20Performance.pdf.

Koch, N, E.K.H.J. zu Ermgassen, J. Wehkamp, F.J.B. Oliveira Filho, and G. Schwerhoff. 2019. "Agricultural Productivity and Forest Conservation: Evidence from the Brazilian Amazon." American Journal of Agricultural Economics 101, no. 3: 919-940.

Kumbhakar, Subal C., Hung-Jen Wang, and Alan Horncastle. 2015. A Practitioner's Guide to Stochastic Frontier Analysis Using Stata. Cambridge University Press. 
MacDicken, K., Ö. Jonsson, L. Piña, S. Maulo, V. Contessa, Y. Adikari, M. Garzuglia, E. Lindquist, G. Reams, and R. D’Annunzio. 2016. "Global forest resources assessment 2015: how are the world's forests changing?." Second Edition, Food and Agricultural Organization of the United Nations. Available at http://www.fao.org/3/a-i4793e.pdf.

Macpherson, Alexander J., Peter P. Principe, and Elizabeth R. Smith. 2010. "A directional distance function approach to regional environmental-economic assessments." Ecological Economics 69, no. 10: 1918-1925.

Margulis, Sergio. 2004. Causes of Deforestation of the Brazilian Amazon. World Bank Working Paper; No. 22. Washington, DC: World Bank. Available at https://openknowledge.worldbank.org/handle/10986/15060 License: CC BY 3.0 IGO.” Mendes, Sérgio Magno, Erly Cardoso Teixeira, and Márcio Antônio Salvato. 2009.

"Investimentos em infra-estrutura e produtividade total dos fatores na agricultura brasileira: 1985-2004." Revista Brasileira de Economia 63, no. 2: 91-102.

National Institute for Space Research (Instituto Nacional De Pesquisas Espaciais - INPE). 2017. Accessed in January 2017 at http://www.inpe.br/

Nepstad, D., G. Carvalho, A. C. Barros, A. Alencar, J. P. Capobianco, J. Bishop, P. Moutinho, P. Lefebvre, U. L. Silva, and E. Prins. 2001. "Road paving, fire regime feedbacks, and the future of Amazon forests." Forest ecology and management 154, no. 3: 395-407.

Nepstad, D., B. Soares-Filho, F. Merry, P. Moutinho, H. O. Rodrigues, M. Bownman, S. Schwartzman, O. Almeida, and S. Rivero. 2007. "The costs and benefits of reducing carbon emissions from deforestation and forest degradation in the Brazilian Amazon." United Nations Framework Convention on Climate Change/Woods Hole Research Center. 
Nepstad, Daniel, David McGrath, Claudia Stickler, Ane Alencar, Andrea Azevedo, Briana Swette, Tathiana Bezerra, Maria DiGiano, João Shimada, Ronaldo Seroa da Motta, Eric Armijo, Leandro Castello, Paulo Brando, Matt C. Hansen, Max McGrath-Horn, Oswaldo Carvalho, Laura Hess. 2014. "Slowing Amazon deforestation through public policy and interventions in beef and soy supply chains." Science 344, no. 6188: 1118-1123.

Quintanilha, J.A., and L. Lee Ho. 2005. “A performance index developed by data envelopment analysis (DEA) to compare the efficiency of fire risk monitoring actions in municipalities of Brazilian Amazon region." 7th International Symposium on Spatial Accuracy Assessment in Natural Resources and Environmental Sciences.

Rada, Nicholas, and Constanza Valdes. 2012. "Policy, Technology, and Efficiency of Brazilian Agriculture." USDA-ERS Economic Research Report 137.

Reis, E., and R. M. Guzmán. 1992. "An econometric model of Amazon deforestation." Texto para Discussao no. 265. Available at http://repositorio.ipea.gov.br/bitstream/11058/4828/1/DiscussionPaper_34.pdf

Rezek, Jon P and Richard K Perrin. 2004. "Environmentally Adjusted Agricultural Productivity in the Great Plains.” Journal of Agricultural and Resource Economics 29(2):346-369.

Rivero, Sérgio, Oriana Almeida, Saulo Ávila, and Wesley Oliveira. 2009. "Pecuária e desmatamento: uma análise das principais causas diretas do desmatamento na Amazônia." Nova economia 19, no. 1: 41-66.

Silva, F., Fulginiti, L., Perrin, R.. 2019a. The Cost of Forest Preservation in the Brazilian Amazon: The “Arc of Deforestation”. Journal of Agricultural and Resource Economics 44(3):497-512 
Silva, F. d., Perrin, R. K. and Fulginiti, L. E. 2019b. The opportunity cost of preserving the Brazilian Amazon forest. Agricultural Economics, 50: 219-227. doi:10.1111/agec.12478

Soares-Filho, Britaldo, Raoni Rajão, Marcia Macedo, Arnaldo Carneiro, William Costa, Michael Coe, Hermann Rodrigues, and Ane Alencar. 2014. "Cracking Brazil's forest code." Science 344, no. 6182: 363-364.

Trindade, F. J., and L. E. Fulginiti. 2015 "Is there a slowdown in agricultural productivity growth in South America?" Agricultural Economics. doi: 10.1111/agec.12199

Villoria, Nelson B., Derek Byerlee, and James Stevenson. 2014. "The Effects of Agricultural Technological Progress on Deforestation: What Do We Really Know?." Applied Economic Perspectives and Policy 36, no. 2: 211-237. 


\section{FIGURES AND TABLES}

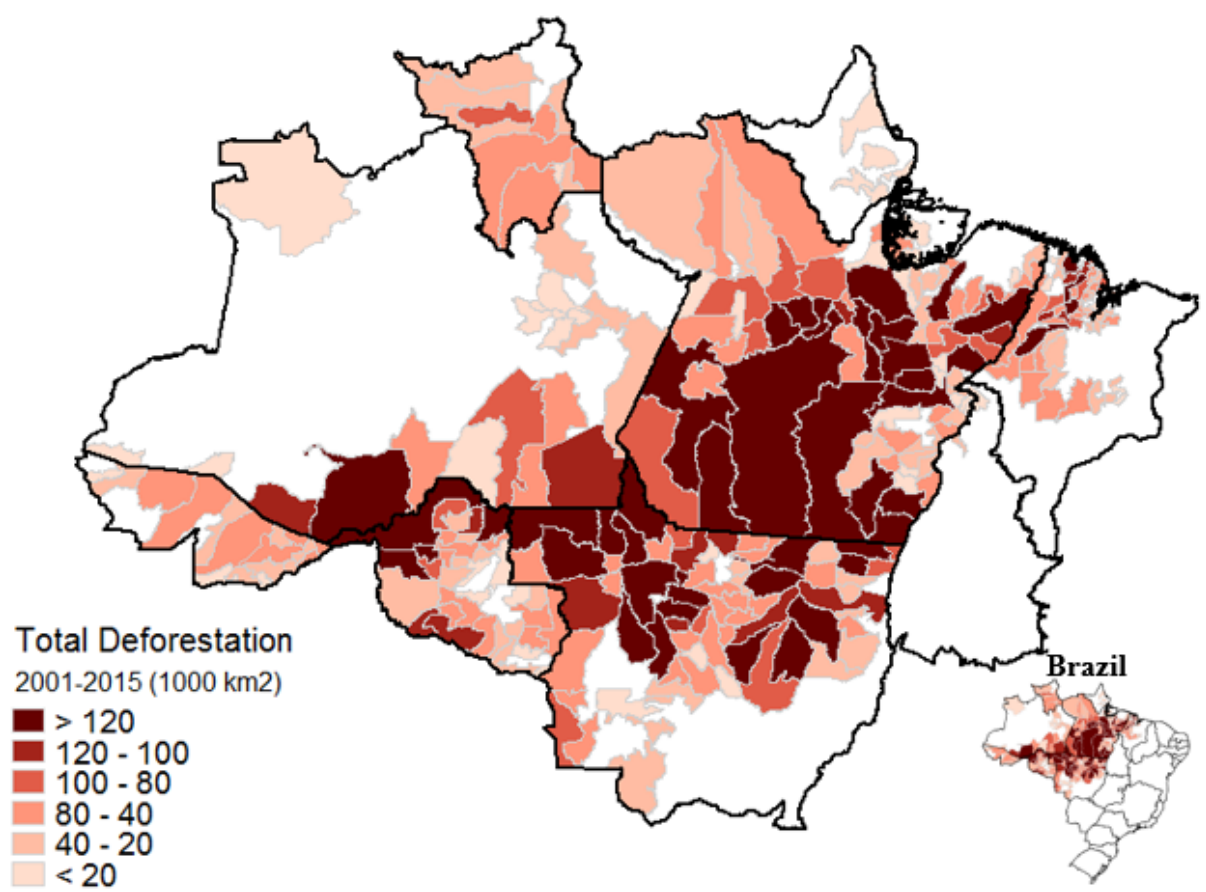

Figure 1. Total deforestation (in $\mathrm{km}^{2}$ ), 2001-2015, in each of the 287 municipalities in the "arc of deforestation" in the northern region of Brazil

Note: White are municipalities not included in the estimation of equation (1). In the application section we describe how we identified the two-hundred eighty seven municipalities.

Source: Authors' estimates using Stata 14, using data obtained from the National Institute for Space Research (INPE/PRODES, 2017). 


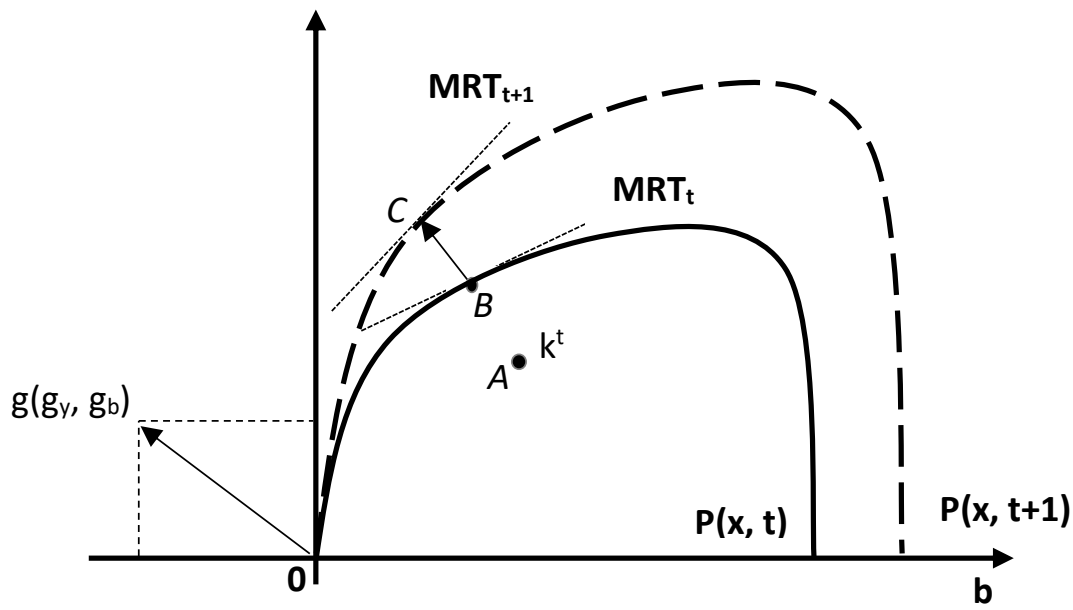

Figure 2. Output Set - $P(x)$, and directional output distance function 
Table 1. Descriptive statistics for agricultural outputs, inputs and deforestation in 287 municipalities with 13,000 ha or more deforested $(94 \%$ of total deforestation) in the arc of deforestation, Brazil, 2003-2015.

\begin{tabular}{|c|c|c|c|c|c|}
\hline & Variable & Mean & $\begin{array}{l}\text { Standard } \\
\text { Deviation }\end{array}$ & Minimum & Maximum \\
\hline \multicolumn{6}{|l|}{ Outputs } \\
\hline Grains (tons) & $y_{1}$ & 69,112 & 275,835 & 0 & $4,584,870$ \\
\hline Livestock (1000 liters) & $y_{2}$ & 5,414 & 8,917 & 0 & 91,953 \\
\hline Timber $\left(m^{3}\right)$ & $y_{3}$ & 40,845 & 114,683 & 0 & $1,521,233$ \\
\hline $\begin{array}{l}\text { GHGemissions (as } \\
\text { deforestation, in ha) }\end{array}$ & $b_{1}$ & 4,621 & 8,683 & 0 & 142,463 \\
\hline \multicolumn{6}{|l|}{ Inputs } \\
\hline Labor (population) & $x_{1}$ & 43,544 & 126,735 & 1225 & $2,020,301$ \\
\hline Capital (head of livestock) & $x_{2}$ & 167,987 & 203,354 & 0 & $2,282,445$ \\
\hline Agricultural area (ha) & $x_{3}$ & 372,896 & 425,683 & 420 & $7,193,020$ \\
\hline
\end{tabular}


Table 2. Average rate and biases of technical change in 287 municipalities with 13,000 ha or more deforested (94\% of total deforestation) in the arc of deforestation, Brazil, 20032015.

\section{COLS MLE}

Rate of technical change

Median

0.0323

0.0334

\begin{tabular}{ccc} 
Mean & $0.0491 * * *$ & $0.0493 * * *$ \\
\hline Bias Grains-emissions $\left(B_{y_{1}, b_{1}}\right)$ & $(0.0043)$ & $(0.0042)$ \\
\hline \multirow{2}{*}{ Bias Livestock-emissions $\left(B_{y_{2}, b_{1}}\right)$} & $0.1573 * * *$ & $0.1480 * * *$ \\
& $(0.0029)$ & $(0.0027)$ \\
Bias Timber-emissions $\left(B_{y_{3}, b_{1}}\right)$ & $0.1383 * * *$ & $0.1673 * * *$ \\
& $(0.010)$ & $(0.0169)$ \\
& $0.1132 * * *$ & $0.1055^{* * *}$ \\
\hline
\end{tabular}

Note: The biases were calculated only on the estimates that satisfy monotonicity. Monotonicity for both grains and livestock was satisfied at $98 \%$, for timber at $92 \%$, and for emissions (deforestation) at $88 \%$ of the 3731 observations. The standard errors for the average technical change were estimated using the Delta method, $* * *$ for p-value smaller than $0.01,{ }^{* *}$ smaller than 0.05 , and $*$ smaller than 0.1 . 


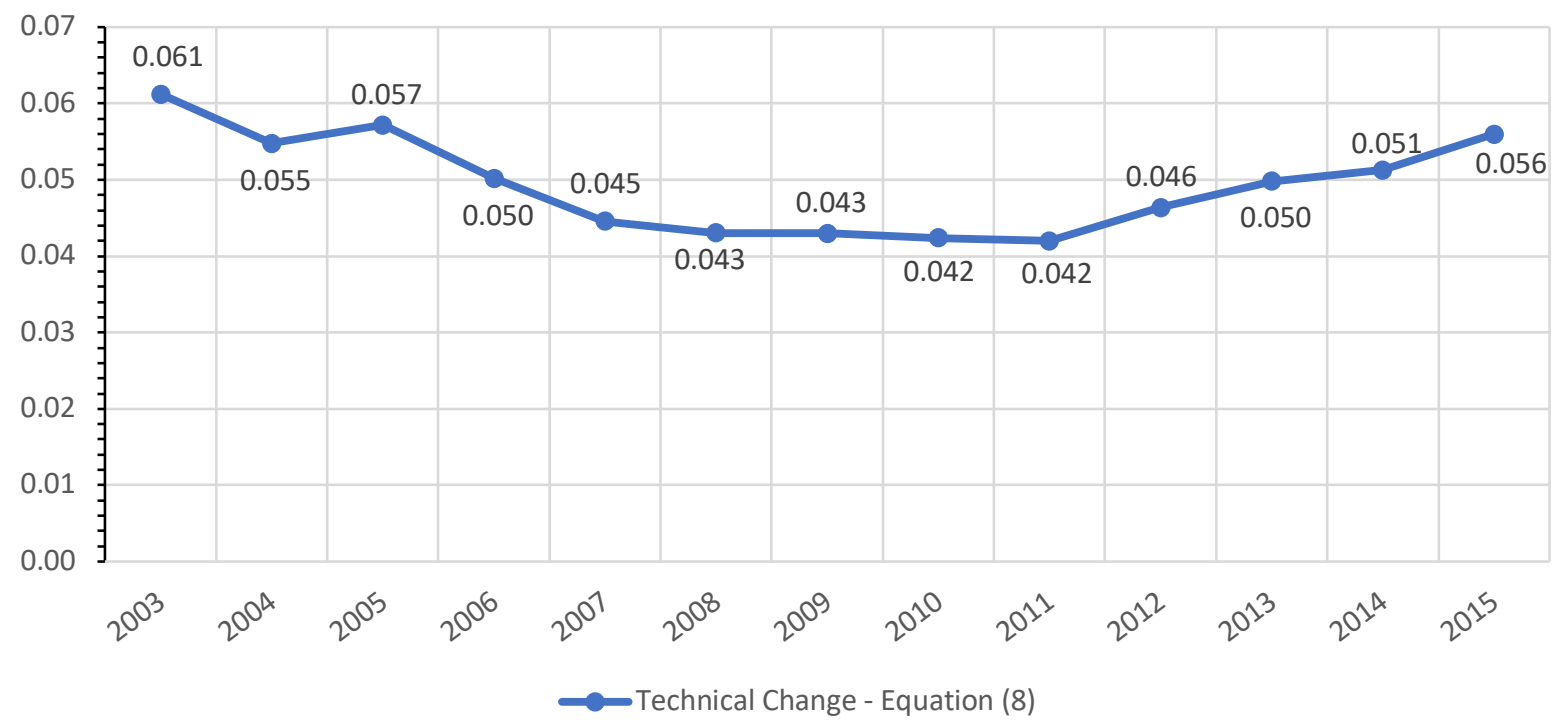

Figure 3. Average rates of technical change in the arc of deforestation, Brazil, from 2003 to 2015. 


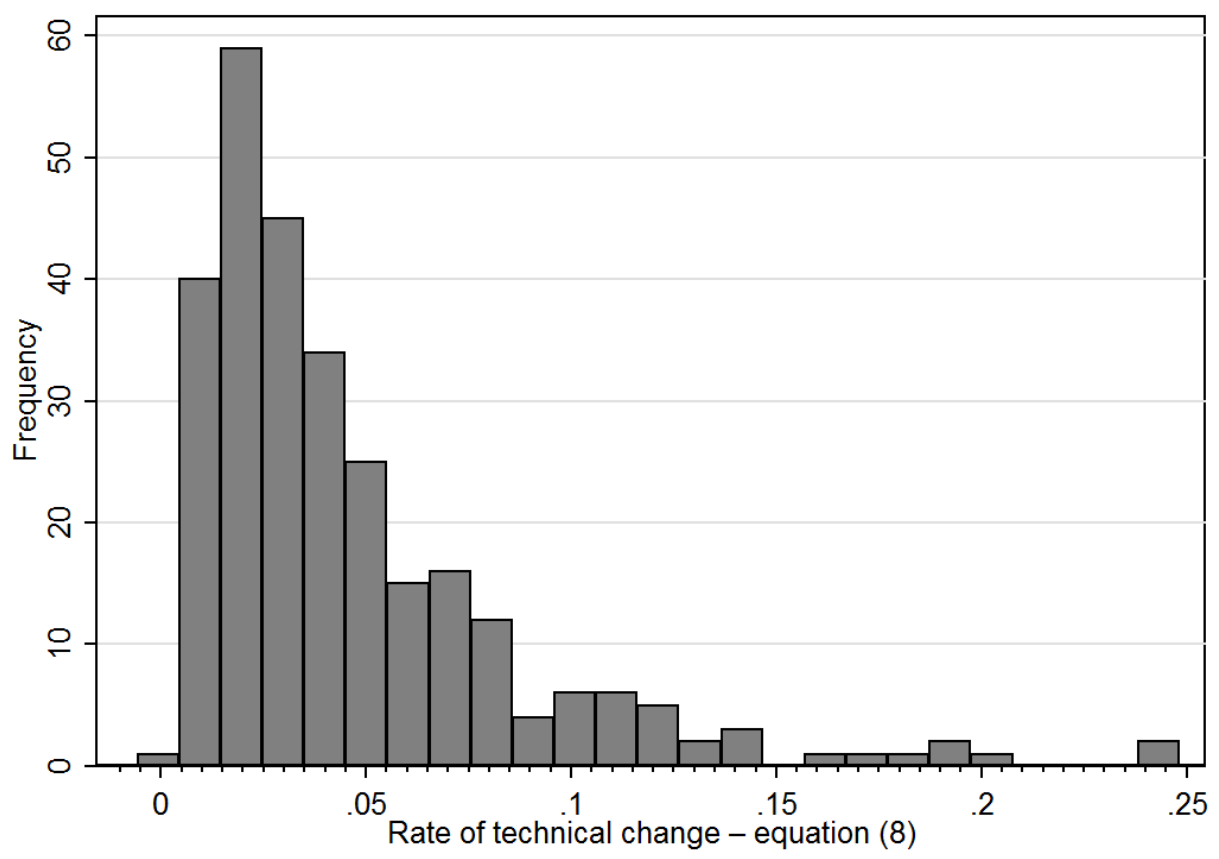

Figure 4. Histogram of average rates of technical change by municipality in the arc of deforestation, Brazil, 2003 to 2015.

Note: The top and bottom $1 \%$ of the sample were dropped to simplify the figure. 


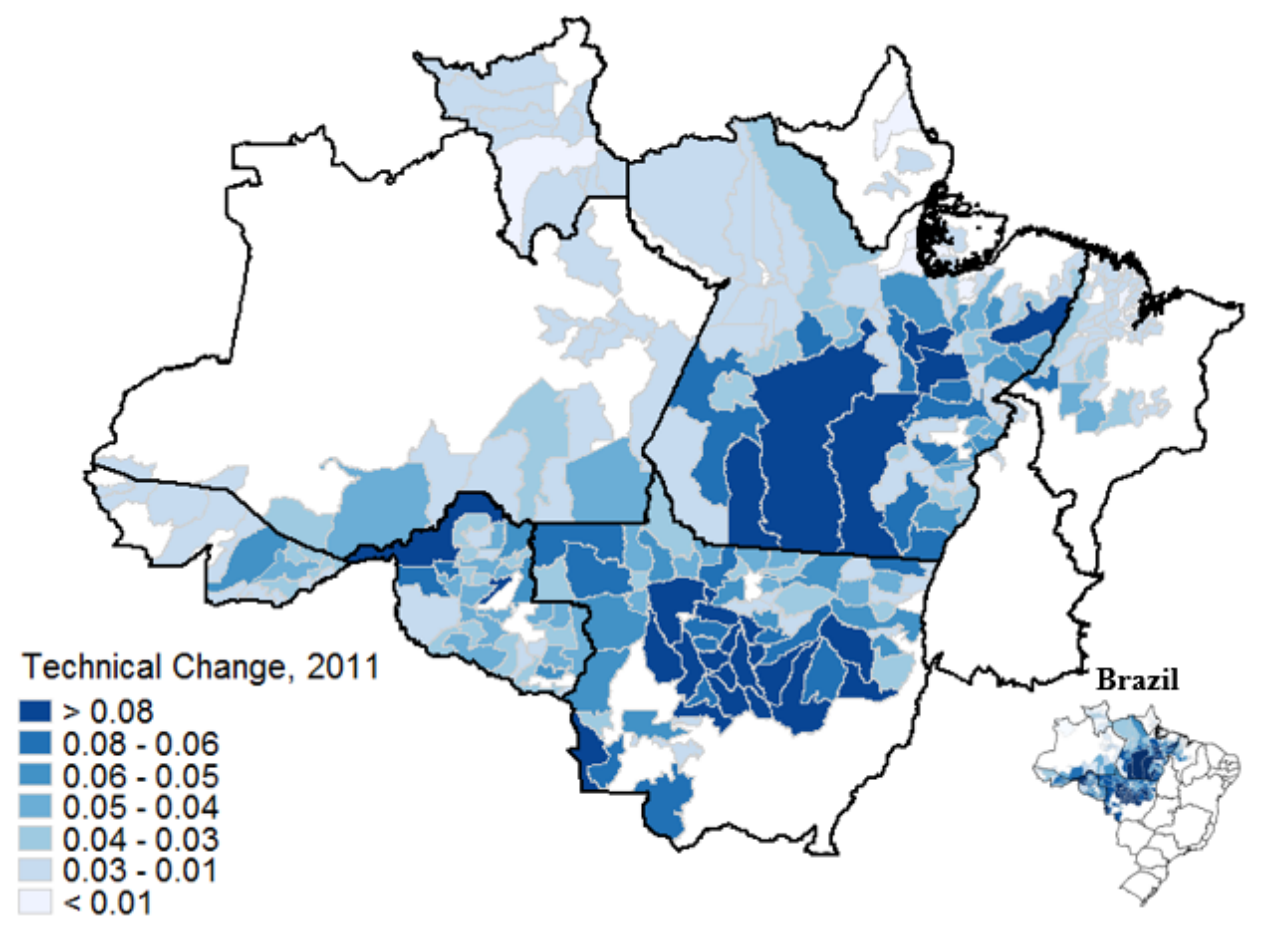

Figure 5. Average rate of technical change in 2011 by municipality in the arc of deforestation, Brazil. 


\section{APPENDIX A}

Table A1. Parameter estimates for the directional distance function under alternative econometric approaches, municipalities in the arc of deforestation, Brazil, 2003-2015.

\begin{tabular}{|c|c|c|c|}
\hline Coefficient & Variable & COLS & MLE \\
\hline$\beta_{1}$ & $y_{1}$ & $\begin{array}{c}-0.2401 * * * \\
(0.0103)\end{array}$ & $\begin{array}{c}-0.2418 * * * \\
(0.0102)\end{array}$ \\
\hline $\boldsymbol{\beta}_{2}$ & $y_{2}$ & $\begin{array}{c}-0.1011 * * * \\
(0.0067)\end{array}$ & $\begin{array}{c}-0.0939 * * * \\
(0.0065)\end{array}$ \\
\hline $\boldsymbol{\beta}_{3}$ & $y_{3}$ & $\begin{array}{c}-0.5326 * * * \\
(0.0105)\end{array}$ & $\begin{array}{c}-0.5254 * * * \\
(0.0104)\end{array}$ \\
\hline$\beta_{11}$ & $y_{1}^{2}$ & $\begin{array}{c}0.0021 * * * \\
(0.0003)\end{array}$ & $\begin{array}{c}0.0022 * * * \\
(0.0003)\end{array}$ \\
\hline$\beta_{22}$ & $y_{2}^{2}$ & $\begin{array}{c}0.0056^{* * * *} \\
(0.0004)\end{array}$ & $\begin{array}{c}0.0053 * * * \\
(0.0004)\end{array}$ \\
\hline$\beta_{33}$ & $y_{3}^{2}$ & $\begin{array}{c}0.0558 * * * \\
(0.0022)\end{array}$ & $\begin{array}{c}0.0572 * * * \\
(0.0021)\end{array}$ \\
\hline$\beta_{12}$ & $y_{1} y_{2}$ & $\begin{array}{c}0.0164 * * * \\
(0.0013)\end{array}$ & $\begin{array}{c}0.0170 * * * \\
(0.0013)\end{array}$ \\
\hline$\beta_{13}$ & $y_{1} y_{3}$ & $\begin{array}{c}-0.0401 * * * \\
(0.0016)\end{array}$ & $\begin{array}{c}-0.0401 * * * \\
(0.0015)\end{array}$ \\
\hline$\beta_{23}$ & $y_{2} y_{3}$ & $\begin{array}{c}-0.0140 * * * \\
(0.0014)\end{array}$ & $\begin{array}{c}-0.0150 * * * \\
(0.0013)\end{array}$ \\
\hline$\gamma_{1}$ & $x_{1}$ & $\begin{array}{l}-0.0275 \\
(0.0494)\end{array}$ & $\begin{array}{l}-0.0156 \\
(0.0466)\end{array}$ \\
\hline$\gamma_{2}$ & $x_{2}$ & $\begin{array}{c}0.3531 * * * \\
(0.0389)\end{array}$ & $\begin{array}{c}0.3776 * * * \\
(0.0367)\end{array}$ \\
\hline$\gamma_{3}$ & $x_{3}$ & $\begin{array}{c}0.0074 \\
(0.0271)\end{array}$ & $\begin{array}{c}0.0069 \\
(0.0256)\end{array}$ \\
\hline$\gamma_{11}$ & $x_{1} x_{1}$ & $\begin{array}{l}0.0021 * \\
(0.0012)\end{array}$ & $\begin{array}{l}0.0019 * \\
(0.0011)\end{array}$ \\
\hline$\gamma_{22}$ & $x_{2} x_{2}$ & $\begin{array}{c}-0.0304 * * * \\
(0.0088)\end{array}$ & $\begin{array}{c}-0.0855 * * * \\
(0.0147)\end{array}$ \\
\hline$\gamma_{33}$ & $x_{3} x_{3}$ & $\begin{array}{c}0.0419 * * * \\
(0.0118)\end{array}$ & $\begin{array}{c}0.0002 \\
(0.0026)\end{array}$ \\
\hline$\gamma_{12}$ & $x_{1} x_{2}$ & $\begin{array}{c}-0.0815 * * * \\
(0.0159)\end{array}$ & $\begin{array}{c}-0.0336 * * * \\
(0.0083)\end{array}$ \\
\hline$\gamma_{13}$ & $x_{1} x_{3}$ & $\begin{array}{c}-0.0553 * * * \\
(0.0143)\end{array}$ & $\begin{array}{c}0.0394 * * * \\
(0.0116)\end{array}$ \\
\hline
\end{tabular}




\begin{tabular}{|c|c|c|c|}
\hline$\gamma_{23}$ & $x_{2} x_{3}$ & $\begin{array}{c}0.0001 \\
(0.0026\end{array}$ & $\begin{array}{c}-0.0473 * * * \\
(0.0133)\end{array}$ \\
\hline$\delta_{11}$ & $y_{1} x_{1}$ & $\begin{array}{c}-0.0607 * * * \\
(0.0040)\end{array}$ & $\begin{array}{c}-0.0619 * * * \\
(0.0038)\end{array}$ \\
\hline$\delta_{12}$ & $y_{1} x_{2}$ & $\begin{array}{c}-0.0350 * * * \\
(0.0054)\end{array}$ & $\begin{array}{c}-0.0328 * * * \\
(0.0052)\end{array}$ \\
\hline$\delta_{13}$ & $y_{1} x_{3}$ & $\begin{array}{c}0.0389 * * * \\
(0.0044)\end{array}$ & $\begin{array}{c}0.0401 * * * \\
(0.0042)\end{array}$ \\
\hline$\delta_{21}$ & $y_{2} x_{1}$ & $\begin{array}{c}-0.0086^{* * *} \\
(0.0013)\end{array}$ & $\begin{array}{c}-0.0070 * * * \\
(0.0014)\end{array}$ \\
\hline$\delta_{22}$ & $y_{2} x_{2}$ & $\begin{array}{c}0.0074 * * * \\
(0.0024)\end{array}$ & $\begin{array}{c}0.0069 * * * \\
(0.0023)\end{array}$ \\
\hline $\boldsymbol{\delta}_{23}$ & $y_{2} x_{3}$ & $\begin{array}{c}0.0008 \\
(0.0020)\end{array}$ & $\begin{array}{l}-0.0005 \\
(0.0018)\end{array}$ \\
\hline$\delta_{31}$ & $y_{3} x_{1}$ & $\begin{array}{c}0.0597 * * * \\
(0.0044)\end{array}$ & $\begin{array}{c}0.0580 * * * \\
(0.0042)\end{array}$ \\
\hline$\delta_{32}$ & $y_{3} x_{2}$ & $\begin{array}{c}0.0136 * * \\
(0.0056)\end{array}$ & $\begin{array}{l}0.0090 * \\
(0.0054)\end{array}$ \\
\hline$\delta_{33}$ & $y_{3} x_{3}$ & $\begin{array}{c}-0.0430 * * * \\
(0.0060)\end{array}$ & $\begin{array}{c}-0.0388 * * * \\
(0.0057)\end{array}$ \\
\hline$v_{1}$ & $t$ & $\begin{array}{c}0.0129 * * \\
(0.0053)\end{array}$ & $\begin{array}{c}0.0016 \\
(0.0054)\end{array}$ \\
\hline$v_{11}$ & $t^{2}$ & $\begin{array}{l}-0.0004 \\
(0.0007)\end{array}$ & $\begin{array}{l}0.0011 * \\
(0.0007)\end{array}$ \\
\hline$\vartheta_{11}$ & $x_{1} t$ & $\begin{array}{c}-0.0022 * * \\
(0.0009)\end{array}$ & $\begin{array}{c}-0.0022 * * * \\
(0.0009)\end{array}$ \\
\hline$\vartheta_{21}$ & $x_{2} t$ & $\begin{array}{c}0.0095 * * * \\
(0.0018)\end{array}$ & $\begin{array}{c}0.0103 * * * \\
(0.0017)\end{array}$ \\
\hline$\vartheta_{31}$ & $x_{3} t$ & $\begin{array}{l}-0.0027 * \\
(0.0015)\end{array}$ & $\begin{array}{l}-0.0025^{*} \\
(0.0014)\end{array}$ \\
\hline$\eta_{1}$ & $y_{1} t$ & $\begin{array}{c}0.0112 * * * \\
(0.0006)\end{array}$ & $\begin{array}{c}0.0112 * * * \\
(0.0006)\end{array}$ \\
\hline$\eta_{2}$ & $y_{2} t$ & $\begin{array}{c}0.0022 * * * \\
(0.0005)\end{array}$ & $\begin{array}{c}0.0023 * * * \\
(0.0005)\end{array}$ \\
\hline$\eta_{3}$ & $y_{3} t$ & $\begin{array}{c}0.0037 * * * \\
(0.0009)\end{array}$ & $\begin{array}{c}0.0035 * * * \\
(0.0009)\end{array}$ \\
\hline $\boldsymbol{\theta}_{1}$ & $b$ & $\begin{array}{c}0.1263 * * * \\
(0.0090)\end{array}$ & $\begin{array}{c}0.1388 * * * \\
(0.0096)\end{array}$ \\
\hline
\end{tabular}




\begin{tabular}{|c|c|c|c|}
\hline$\mu_{1}$ & $y_{1} b$ & $\begin{array}{c}-0.0216^{* * *} \\
(0.0013)\end{array}$ & $\begin{array}{c}-0.0209 * * * \\
(0.0012)\end{array}$ \\
\hline$\mu_{2}$ & $y_{2} b$ & $\begin{array}{c}0.0080 * * * \\
(0.0011)\end{array}$ & $\begin{array}{c}0.0073 * * * \\
(0.0011)\end{array}$ \\
\hline$\mu_{3}$ & $y_{3} b$ & $\begin{array}{c}0.0016 \\
(0.0011)\end{array}$ & $\begin{array}{l}0.0021 * \\
(0.0011)\end{array}$ \\
\hline $\boldsymbol{\theta}_{11}$ & $b b$ & $\begin{array}{c}-0.0119 * * * \\
(0.0012)\end{array}$ & $\begin{array}{c}-0.0115 * * * \\
(0.0012)\end{array}$ \\
\hline$\varphi_{1}$ & $b x_{1}$ & $\begin{array}{c}-0.0096 * * * \\
(0.0026)\end{array}$ & $\begin{array}{c}-0.0109 * * * \\
(0.0025)\end{array}$ \\
\hline$\varphi_{2}$ & $b x_{2}$ & $\begin{array}{c}-0.0140 * * * \\
(0.0033)\end{array}$ & $\begin{array}{c}-0.0169 * * * \\
(0.0032)\end{array}$ \\
\hline$\varphi_{3}$ & $b x_{3}$ & $\begin{array}{l}-0.0033 \\
(0.0053)\end{array}$ & $\begin{array}{c}0.0008 \\
(0.0051)\end{array}$ \\
\hline$\lambda_{1}$ & $b t$ & $\begin{array}{c}0.0171 * * * \\
(0.0010)\end{array}$ & $\begin{array}{c}0.0170 * * * \\
(0.0010)\end{array}$ \\
\hline$\gamma_{0}$ & Constant & $\begin{array}{c}-0.2065^{* *} \\
(0.0945)\end{array}$ & $\begin{array}{l}-0.0774 \\
(0.0899)\end{array}$ \\
\hline$\sigma_{u}$ & & - & $\begin{array}{c}-2.7958 * * * \\
(0.1457)\end{array}$ \\
\hline$\sigma_{v}$ & & - & $\begin{array}{c}-3.5791 * * * \\
(0.1033)\end{array}$ \\
\hline$\lambda_{M L E}$ & & - & $\begin{array}{c}1.4794 * * * \\
(0.0262)\end{array}$ \\
\hline
\end{tabular}

Note: COLS parameters used as starting values for MLE. Standard error in parenthesis; $* * *$ for $\mathrm{p}$-value smaller than $0.01, * *$ smaller than 0.05 , and $*$ smaller than 0.1 . The dependent variable is the negative of average deforestation.

$\lambda_{M L E}$ refers to the estimated $\sigma_{u} / \sigma_{v}$ instead of the parameter associated with the interaction between undesirable output and time trend (Eq. 7). In the two methods, we include municipality dummies, available upon request.

Parameters for deforestation, are recovered using the translation property. 3731 observations were used in these regressions. 